

\title{
Photographs, Correspondence, and Presentations Related to the La Conchita, California, Landslide
}

\author{
By Randall W. Jibson
}

Open-File Report 2006-1278 


\section{U.S. Department of the Interior DIRK KEMPTHORNE, Secretary \\ U.S. Geological Survey \\ P. Patrick Leahy, Acting Director}

\section{U.S. Geological Survey, Reston, Virginia: 2006}

For product and ordering information:

World Wide Web: http://www.usgs.gov/pubprod

Telephone: 1-888-ASK-USGS

For more information on the USGS--the Federal source for science about the Earth, its natural and living resources, natural hazards, and the environment:

World Wide Web: http://www.usgs.gov

Telephone: 1-888-ASK-USGS

Any use of trade, product, or firm names is for descriptive purposes only and does not imply endorsement by the U.S. Government.

Although this report is in the public domain, permission must be secured from the individual copyright owners to reproduce any copyrighted materials contained within this report.

Suggested citation:

Jibson, R.W., 2006, Photographs, correspondence, and presentations related to the La Conchita, California, Landslide: U.S. Geological Survey Open-File Report 2006-1278. 


\title{
Photographs, Correspondence, and Presentations related to the La Conchita, California, Landslide
}

\author{
By Randall W. Jibson
}

\section{Introduction}

This report contains the following photographs and information related to the La Conchita, California, landslide:

- Digital photographs taken by the author during a visit to the La Conchita landslide on January 14, 2005.

- Correspondence related to the approval and release of USGS Open-File Report 2005-1067, Landslide Hazards at La Conchita, California.

- A presentation on the La Conchita landslide that has been given to various organizations and groups since 2005. 